\title{
STRATEGI PROMOSI PENERIMAAN SISWA BARU (STUDI KASUS SMK KESEHATAN CIPTA BHAKTI HUSADA YOGYAKARTA)
}

\author{
Oleh: \\ Ardiyanto Wardhana \\ Dosen Ilmu Komunikasi UAD Yogyakarta \\ E-mail; arddi_wd@yahoo.com
}

\begin{abstract}
Intisari
Adanya persaingan antar sekolah yang semakin meningkat beberapa waktu belakangan ini, maka upaya pemasaran untuk di sebuah lembaga pendidikan mutlak diperlukan. Sekolah sebagai lembaga penyedia jasa pendidikan perlu berbenah diri serta belajar agar memiliki inisiatif untuk dapat meningkatkan kepuasan pelanggan dalam hal ini siswa maupun siswi. Di zaman serba kompetitif seperti halnya saat ini, sesuatunya akan menjadi sulit apabila organisasi untuk dapat hidup dengan baik jika tidak memiliki kemampuan mengubah diri atau mempromosikan diri dengan baik serta secara cepat mampu berkembang dan memahami berbagai tuntutan yang diinginkan oleh para stakeholder. Oleh sebab itu, maka diperlukanlah strategi promosi khususnya di bidang jasa pendidikan yang tepat untuk memenangkan sebuah kompetisi antar sekolah sehingga meningkatkan animo calon peserta didik baru atau siswa, dan juga untuk meningkatkan akselerasi peningkatan kualitas dan profesionalisme manajemen sekolah. Penelitian ini menggunakan deskriptif kualitatif dengan studi kasus tunggal terpancang. Data dalam penelitian kualitatif ini diperoleh melalui human dan nonhuman. Sumber human diperoleh melalui wawancara (interview) dan atau observasi dengan mencatat tanda-tanda nonverbal yang ditransmisikan ke dalam bentuk catatan lapangan (field notes) ketika interview atau pada saat observasi berlangsung sedangkan untuk sumber nonhuman meliputi dokumen, rekaman, tempat dan sebagainya.
\end{abstract}

Kata kunci: Komunikasi Pemasaran, Keahlian, Dunia Kerja 


\begin{abstract}
The existence of competition between schools has increased some time lately, then the marketing efforts for an educational institution is absolutely necessary. Schools as educational service providers need to improve themselves and learn to have the initiative to increase customer satisfaction in this case students and girls. In today's competitive era as it is today, things are going to be difficult if organizations can live well if they do not have the ability to change themselves or promote themselves well and quickly develop and understand the demands that stakeholders want. Therefore, it is necessary to promote strategies especially in the field of education services to win an inter-school competition so as to increase the interest of prospective new students or students, as well as to improve the acceleration of quality improvement and professionalism of school management. This study used descriptive qualitative with single case study stuck. Data in this qualitative research is obtained through human and nonhuman. Human resources are obtained through interviews and / or observations by noting nonverbal signs transmitted into field notes during interviews or during observations while for nonhuman sources including documents, recordings, places and so on.
\end{abstract}

Keywords: Marketing Communications, Expertise, World of Work

\title{
A. PENDAHULUAN
}

Seiring derasnya tantangan globalisasi, maka di saat yang sama, hal tersebut juga berlaku tantangan di dalam dunia pendidikan pun menjadi semakin besar, hal ini yang akan mendorong para siswa maupun siswi akan mendapatkan prestasi terbaik. Sekolah merupakan salah satu poin penting yakni sebagai salah satu pembentuk karakter bangsa di mana para kaum muda akan bertarung di kancah global. Sudah menjadi perbincangan, bahwa persaingan antar sekolah di Indonesia dewasa ini semakin tajam. Hal ini tentunya menjadi sinyal positif dalam hal peningkatan kualitas penyelenggaraan pendidikan.

Adanya persaingan antar sekolah yang semakin meningkat beberapa waktu belakangan ini, maka upaya pemasaran untuk di sebuah lembaga pendidikan mutlak diperlukan. Sekolah sebagai lembaga penyedia jasa pendidikan perlu berbenah diri serta belajar agar memiliki inisiatif untuk dapat meningkatkan kepuasan pelanggan dalam hal ini siswa maupun siswi. Oleh sebab itu, maka diperlukanlah strategi promosi khususnya di bidang jasa pendidikan yang tepat untuk memenangkan sebuah kompetisi antar sekolah sehingga meningkatkan animo calon peserta didik baru atau siswa, dan juga untuk meningkatkan akselerasi peningkatan kualitas dan profesionalisme manajemen sekolah.

Pada saat sekarang ini peran Sekolah Menengah Kejuruan (SMK) tidak bisa lagi dianggap sebelah mata. Tidak adalagi kedudukan SMK sebagai sekolah yang selalu diartikan menjadi pilihan kedua apabila tidak dapat masuk ke Sekolah Menengah Atas (SMA) yang diinginkan.

Di dalam sejarah dunia pendidikan di Indonesia, sebelum dikenal dengan SMK, telah lebih dahulu dikenal dengan nama Sekolah Teknologi Menengah (STM) yang merupakan akronim dari Sekolah Teknologi Menengah, selain dua hal di atas ada lagi 
dengan istilah SMEA yakni singkatan dari Sekolah Menengah Ekonomi Atas, ada juga Sekolah Menengah Industri dan Kerajinan disingkat dengan SMIK, Sekolah Menengah Musik (SMM) dan lain sebagainya.

Sekolah Menengah Kejuruan (SMK) merupakan salah satu bentuk satuan pendidikan formal yang menyelenggarakan pendidikan di tingkat kejuruan yakni pada jenjang pendidikan menengah sebagai lanjutan dari SMP, MTs, atau bentuk lain yang sederajat atau lanjutan dari hasil belajar yang diakui sama/setara SMP/MTs. SMK sering disebut juga STM (Sekolah Teknik Menengah). Di SMK, terdapat banyak sekali Program Keahlian.

Di zaman serba kompetitif seperti halnya saat ini, sesuatunya akan menjadi sulit apabila organisasi untuk dapat hidup dengan baik jika tidak memiliki kemampuan mengubah diri atau mempromosikan diri dengan baik serta secara cepat mampu berkembang dan memahami berbagai tuntutan yang diinginkan oleh para stakeholder.

Persaingan yang ketat saat ini memaksa lembaga pendidikan untuk merancang, menggunakan strategi pemasaran yang baik dan tepat dalam menarik calon siswa atau peserta didik baru. Dengan adannya strategi pemasaran yang tepat lembaga kursus dapat bertahan dan berkembang. Persaingan antar lembaga pendidikan kejuruan sebenarnya memberikan keuntungan bagi konsumen, dalam hal ini calon siswa, hal ini disebabkan konsumen memiliki banyak pilihan dalam memutuskan lembaga yang cocok untuk calon siswa.

Menjelang tahun ajaran baru, proses penerimaan peserta siswa baru wajib telah selesai dilaksanakan. Pengelolaan yang dimulai pada proses penerimaan peserta siswa baru harus segera diimplementasikan oleh sekolah. Tindakan awal pada penerimaan peserta didik baru yaitu mengadakan pertemuan kepala sekolah dengan guru-guru yang berkaitan dengan tugas dan tanggung jawab dalam penerimaan peserta didik baru guna menyusun rencana publikasi penerimaan peserta didik baru.

Animo masyarakat yang dahulunya menyekolahkan anaknya di tingkat SMA, namun saat ini SMK menjadi salah satu pilihan penting, bahkan dalam beberapa hal SMK mampu mengalahkan dominasi calon siswa yang ingin bersekolah ke SMA. Secara realita, hal ini disebabkan karena kebutuhan masyarakat yang semakin menyadari bahwa kompetensi serta keterampilan yang mumpuni lah yang akan mampu bersaing di dunia kerja.

Di mana di SMK, orientasi pendidikan lebih ditekankan pada bagaimana setelah menyelesaikan studi bisa segera mendapatkan pekerjaan. Mungkin hal ini dianggap lebih realistis mengingat beban hidup masyarakat yang semakin berat, sementara biaya studi untuk melankutkan ke perguruan tinggi menanjak terus atau dengan kata lain semakin mahal. Pilihan tahapan selangkah demi selangkah merupakan strategi yang lebih cerdas. Hal ini dikarenakan, setelah lulus SMK, siswa masih dapat meneruskan pendidikan ke perguruan tinggi atau ada juga yang berpikir bahwa yang terpenting bekerja terlebih dahulu untuk mendapatkan penghasilan, namun setelah itu bisa melanjutkan ke bangku kuliah.

Meningkatnya animo lulusan SMP melanjutkan ke SMK juga disebabkan keberhasilan pemerintah menyosialisasikan pentingnya SMK melalui iklan layanan masyarakat di televisi maupun media cetak. Pergeseran animo masyarakat dari SMA ke 
SMK di satu sisi memberikan optimisme terhadap persoalan penganggur lulusan SMA, yang memang kurikulumnya didesain bukan untuk bekerja.

\section{B. TINJAUAN PUSTAKA}

\section{Strategi}

Strategi dapat dipahami sebagai suatu rencana yang cermat, yang terkait dengan cara-cara pendayagunaan dan penggunaan sumber daya yang ada untuk meningkatkan efektifitas dan efisiensi dalam mencapai suatu sasaran tertentu. Dengan kata lain Strategi di dalam manajemen sebuah organisasi, dapat diartikan sebagai cara, ataupun taktik utama yang dirancang secara sistematik dalam melaksanakan fungsi - fungsi manajemen, yang terarah pada tujuan strategic organisasi

Kata "strategi" berasal dari bahasa Yunani, yakni strategos yang diterjemahkan sebagai "komandan militer” di zaman demokrasi Athena. Menurut kotler (1997) strategi sebagai permainan utuk mencapai sasaran usaha dengan menggunakan pemikiran strategis. Konsep strategi banyak dipakai dalam berbagai bidang tidak terkecuali dalam dunia bisnis misalnya Sun Tzu, (dalam The Art War), Hannibal dan Carl Clausewitz.

Begitu pula hal nya dengan promosi, di dalam mengimplementasikan sebuah strategi promosi maka tidaklah lengkap bila tidak mengikutsertakan unsur komunikasi di dalamnya. Hal ini disebabkan sebaik apapun di dalam merancang strategi promosi apabila tidak ada unsur komunikasinya maka program tersebut dapat dikatakan akan berjalan kurang efektif dan efisien.

Untuk dapat memenangkan persaingan perusahaan perlu strategi yang tepat dalam menjalankan operasionalnya, sehingga dapat menciptakan profit yang optimal, awal mula yang perlu dilakukan adalah memulai dengan menciptakan customer value yang pada akhirnya nanti diharapkan akan mampu menarik minat pelanggan dan mampu mendatangkan keuntungan bagi organisasi ataupun perusahaan.

Di setiap strategi bisnis diperlukan komunikasi yang baik antara komunikator dengan komunikan dalam hal ini penjual dan pembeli. Bila komunikasi yang dibangun telah terjalin dengan baik maka akan dengan mudah membujuk mereka apa yang mereka jual. Seringkali unsur komunikasi bagi pelaku pemasaran atau pebisnis diabaikan. Mereka menjual produk tanpa berkomunikasi baik secara langsung maupun tidak langsung dengan para konsumennya. Banyak sekali manfaat yang diambil apabila unsur komunikasi digunakan dalam proses strategi pemasaran

Menurut Schendel dan Hofel dalam Syaiful Sagala, (2007: 139) implementasi strategi dicapai melalui alat administrasi yang dapat dikelompokkan ke dalam tiga kategori, yaitu:

a. Struktur, yaitu siapa yang bertanggung jawab terhadap apa yang di kerjakan oleh bawahannya.

b. Proses, yaitu bagaimana tugas dan tanggung jawab yang dikerjakan masingmasing personel.

c. Tingkah laku, yaitu perilaku yang menggambarkan motivasi, semangat kerja, penghargaan, disiplin, etika dan sebagainya. 
Diperlukan suatu struktur yang jelas, terarah disertai juga bagaimana menjalankan tugas dan kewajiban serta dapat saling memberikan motivasi atau dukungan agar semua bagian ataupun sistem di dalam strukturs tersebut mampu menjalankan tugas yang di kerjakan selesai tepat pada waktunya.

\section{Promosi}

Strategi promosi yang benar akan berdampak baik. Hal ini juga berlaku pada kuantitas pendaftar, khususnya bagi suatu seolah yang sedang mencari siswa baru. Jumlah siswa menjadi ukuran keberhasilan promosi yang sudah dilakukan. Sehebat apapun kualitas sekolah jika tanpa promosi yang baik maka keberhasilan mendapatkan siswa baru akan berkendala, dan bisa sepi pendaftar.

Unsur utama dalam pemasaran dapat diklasifikasikan menjadi tiga unsur (Ara hidayat \& Imam Machali (2012)

1. Unsur strategi persaingan, meliputi Segmentasi pasar, yaitu tindakan mengidentifikasi dan membentuk kelompok pembeli atau konsumen secara terpisah. Targetting, yaitu tindakan memilih satu atau lebih segmen pasar yang akan dimasuki. Positioning, yaitu penetapan posisi pasar. Tujuannya adalah membangun dan mengkomunikasikan keunggulan bersaing produk yang ada di pasar ke dalam benak konsumen.

2. Unsur taktik pemasaran, meliputi Differensiasi, yaitu yang terkait dengan cara membangun strategi pemasaran di berbagai aspek perusahaan. Kegiatan membangun strategi pemasaran inilah yang membedakan differensiasi yang dilakukan suatu perusahaan dengan perusahaan lainnya. Bauran pemasaran (marketing mix), terkait dengan kegiatan mengenai produk, harga, promosi, dan tempat atau yang lebih dikenal dengan sebutan 4P, yaitu Product, Price, Promotion, dan Place.

3. Unsur nilai pemasaran, yang berkaitan dengan: nama, termin, tanda simbol, atau desain, atau kombinasi dari semuanya, yang ditujukan untuk mengidentifikasikan barang atau jasa sebuah/sekelompok penjual dan membedakannya dengan para pesaing. Merek mempunyai banyak arti penting buat konsumen, yaitu Sebagai identifikasi untuk membedakan antara satu produk dengan produk lain. Identifikasi ini diperlukan agar konsumen mempunyai kebebasan memilih produk dan merek mana yang memenuhi kebutuhannya. Kemudian Sebagai garansi atas kualitas dan kinerja dari produk yang akan dibeli. Merek akan memberikan rasa percaya diri kepada konsumen. Merek memberi status dan image pada seseorang. Merek memberi arti emosional.

\section{Komunikasi Pemasaran}

Yang menjadi kunci suksesnya suatu kegiatan pemasaran adalah promosi. Secara umum promosi dapat dilakukan melalui beberapa faktor atau elemen. Adapun kegiatan komunikasi pemasaran mempunyai elemen-elemen (Belch and Belch, 2004: 16) yakni Periklanan (advertising), merupakan awal dalam memasarkan sebuah produk, berfungsi untuk menginformasikan serta mempengaruhi konsumen agar bersedia menggunakan produk atau jasa yang ditawarkan. Sifatnya yang mampu menembus menjadikan iklan 
banyak digunakan untuk mempengaruhi konsumen yang besar. Bentuk iklan merupakan yang terdapat di media massa cetak maupun elektronik, seperti brosur, billboard, logo. Iklan juga dapat digunakan untuk membuat sebuah citra terhadap merek hal ini berpengaruh terhadap kredibilitas perusahaan sebagai produsen yang mengeluarkan produk. Selain itu melalui iklan dapat menjadikan produk yang ditawarkan berbeda dengan produk lainnya sehingga mempunyai daya jual yang tinggi. Melalui iklan juga dapat mengembangkan kesadaran merek (brand awareness) dan citra positif yang pada akhirnya akan meraih konsumen yang lebih. Kemudian ada Pemasaran Langsung (Direct Marketing), Pemasaran Langsung merupakan kegiatan promosi yang ditujukan langsung kepada konsumen dengan harapan akan mendapat respon, seperti surat, e-mail, dan telepon. Pemasaran langsung meliputi berbagai aktivitas seperti manajemen database, penjualan langsung, telemarketing serta iklan respon langsung melalui direct mail seperti internet. Terjadinya perubahan gaya hidup dimana seseorang tidak perlu lagi berbelanja dengan mengunjungi toko tetapi dapat melalui telepon. Setelah itu ada tahapan Interaktif/pemasaran internet (interactive/internet marketing), yakni menggunakan internet untuk melakukan kegiatan pemasaran, khususnya melalui World Wide Web. Sifatnya yang menarik menjadikan internet sebagai media promosi efektif untuk berkomunikasi dengan konsumen. Promosi penjualan (sales promotion), merupakan aktivitas marketing yang memberikan nilai atau insentif ekstra untuk satuan penjualan, distributor atau konsumen akhir dan dapat menstimulasi penjualan langsung. Publisitas/hubungan masyarakat (publicity/public relations), Publisitas adalah bentuk penyajian dan penyebaran ide, barang dan jasa secara non personal, yang mana orang atau organisasi yang diuntungkan tidak membayar untuk itu. Terakhir ada tahapan Penjualan perorangan (personal selling). Tahapan ini merupakan komunikasi yang dilakukan secara langsung atau tatap muka antara penjual dan pembeli. Dari interaksi tersebut marketer dapat melihat komunikasi yang dilakukan bersifat fleksibel, dalam arti penjual diperbolehkan untuk menyesuaikan pesan dengan kebutuhan atau situasi konsumennya.

\section{PEMBAHASAN}

\section{Industry Sekolah Kejuruan}

Menghadapi persaingan yang semakin ketat ini, siswa sekolah tidak hanya dituntut memiliki kemampuan analisis maupun teoritis belaka. Namun juga harus ahli atau menguasai teknologi berdasar kemampuan yang didapat pada saat di bangku sekolah. SMK yang dahulu di sebut STM (Sekolah Teknologi Menengah) mampu kiranya menjawab tantangan zaman. Hal tersebut dapat dilihat dari beberapa jurusan yang dipelajari di SMK seperti otomotif ataupun multimedia. Tidak hanya mengembangkan SDM (Sumber Daya Manusia) nya saja SMK juga berkomitmen untuk mengurangi jumlah pengangguran usia produktif.

Di akhir tahun 2015 Masyarakat Ekonomi Asean (MEA) resmi akan dimulai secara bertahap, di mana kelak dalam masyarakat tersebut perdagangan barang, jasa, investasi, modal, dan tenaga kerja ahli akan dibebaskan. 
Orientasi tujuan pendidikan kejuruan pada prinsipnya adalah untuk mendukung 3 pilar kebijakan pendidikan nasional, yang pertama adalah membekali ketrampilan dan penguasaan kompetensi tamatan sesuai dengan kebutuhan pasar kerja, yaitu untuk memenuhi kebutuhan tenaga kerja di tingkat lokal, regional, nasional maupun global. Kedua adalah dengan membekali keterampilan dan penguasaan kompetensi serta memiliki kemampuan berwirausaha untuk dapat menjadi tenaga yang mandiri, mampu menciptakan lapangan kerja dan menjadi wirausaha unggul (interpreneur). Sedangkan poin yang ketiga adalah dengan membekali ketrampilan dan penguasaan kompetensi serta kemampuan akademis untuk menyiapkan tamatan yang dapat melanjutkan kejenjang yang lebih tinggi

Berdasarkan data yang terdapat di Kemendikbud (http://publikasi.data.kemdikbud.go.id/uploadDir/isi_234E39B6-621B-40AD-8E1E-

FB84611A804D_pdf) terdapat 13.236 jumlah SMK Negeri maupun Swasta yang tersebar di seluruh Indonesia. Ini tentu saja hal yang menggembirakan, mengingat saat ini sekolah kejuruan tidak hanya sebagai sekolah ke 2 tapi juga sekolah dengan daya saing bagi sekolah-sekolah formal lainnya.

\section{Strategi Promosi SMK Kesehatan Cipta Bhakti Husada Yogyakarta}

Pemerintah saat ini sedang gencar-gencarnya melakukan upaya promosi SMK dan sudah sejak lama SMK merupakan sekolah yang identik dengan pencetak orang-orang yang handal dan memiliki keahlian khusus didunia kerja. Di dalam Penerimaan Peserta Didik Baru (PPDB), promosi merupakan langkah awal dalam merencanakan penerimaan siswa baru. Apabila tidak dilakukan dengan langkah yang tepat, maka dapat dipastikan peminat untuk bersekolah di SMK menjadi sepi peminat. Sehingga promosi menjadi ujung tombak menarik siswa baru.

Elemen-elemen komunikasi pemasaran, seperti periklanan, pemasaran langsung, Interaktif/pemasaran internet, Promosi penjualan, Publisitas/hubungan masyarakat dan Penjualan perorangan dilakukan untuk menggaet siswa baru. Tentu saja dengan upayaupaya yang maksimal

1. Periklanan (advertising)

Beriklan melalui brosur sudah menjadi poin utama bagi SMK Kesehatan Cipta Bhakti Husada sejak awal didirikan di tahun 2012. Tidak hanya penyebaran brosur di depan pintu sekolah menengah (SMP/MTs) akan tetapi juga menjalin kerjasama dengan sekolah yang dituju dalam bentuk presentasi, menempel poster dan mendistribusikan brosur kepada siswa dan siswi di sekolah menengah tersebut. Bahkan tidak hanya itu, ada insentif yang akan diberikan dalam bentuk tali asih apabila ada siswa nya yang mendaftar dan mendaftar ulang di SMK CBH Yogyakarta.

2. Pemasaran Langsung (Direct Marketing)

Hingga saat ini langsung berinteraksi dengan para siswa SMP tingkat akhir atau kelas 9 merupakan cara jitu untuk menarik sebanyak mungkin calon siswa yang berminat masuk SMK. Kemampuan komunikator menjelaskan kelebihan unggulan sekolah didepan para siswa diharap mampu menggaet calon siswa smk lebih banyak lagi.

3. Interaktif/pemasaran internet (interactive/internet marketing), 
Untuk bauran pemasaran ini belum banyak yang bias dioptimalkan. Yang ada hanya sebatas pengumuman agenda sekolah ataupun jadwal penerimaan siswa baru. Ini dikarenakan mayoritas yang masuk di SMK Kesehatan Cipta Bhakti Husada tidak terlalu familiar dengan jaringan internet ataupun social media. Upaya yang lebih maksimal dianggap adalah media televisi.

4. Promosi penjualan (sales promotion)

Upaya ini paling sering dilakukan di hampir setiap sekolah baik calon siswa SMP maupun SMA. Para perwakilan sekolah yang memburu calon siswa nya mengagendakan untuk melakukan presentasi langsung didepan siswa nya. Begitu pula dengan SMK Kesehatan Cipta Bhakti Husada. Perwakilan sekolah melakukan promosi di setiap pameran pendidikan yang diselenggarakan oleh pemerintah atau pihak terkait. Ini mampu menarik animo calon siswa untuk mendaftar mengingat di saat promosi berlangsung factor pendukung promosi penjualan sperti halnya brosur ikut disertakan untuk dibawa pulang bagi calon siswa nya sebagai pertimbangan saat lulus sekolah tingkat menegah

5. Publisitas/hubungan masyarakat (publicity/public relations),

Membangun citra sebagai sekolah kejuruan yang memiliki insan berakhlak mulia mandiri, unggul dalam iptek, dan terampil dalam bidang kesehatan sesuai dalam visi sekolah mampu meningkatkan citra yang positif sekolah di masyarakat. Citra bagi sekolah kejuruan merupakan penilaian individu terhadap sekolah tersebut dikarenakan pemahaman akan suatu informasi. Sebagai SMK Kesehatan satu-satunya yang dikunjungi Ketua DPRD dari Jepang mampu menciptakan citra korporasi yang baik. Bahkan tidak hanya itu kerjasama yang diadakan juga dilakukan dengan PD PAFI DIY DInkes DIY, Lembaga Sertifikasi Profesi Asnakes dan Patkesindo mampu mempertahankan citra positif di masyarakat terkait SMK Kesehatan.

6. Penjualan perorangan (personal selling)

Kegiatan ini sering dilakukan di saat adanya pameran pendidikan yang biasanya dilakukan oleh pemerintah daerah. Bersentuhan langsung dengan calon siswa menjadi factor penentu seorang siswa memilih sekolah kejuruan yang diminatinya. Faktor kemudahan dalam mendapatkan pekerjaan pasca lulus dari sekolah kejuruan kerapkali menjadi banyak pertanyaan bagi orang tua calon siswa. Ini tentu saja menjadi kunci bagi sekolah. Karena SMK memang di peruntukkan yang mempunyai keahlian khusus dan siap kerja.

\section{KESIMPULAN}

Di Indonesia, Yogyakarta merupakan salah satu kota yang memiliki bermacam predikat yang disematkan, diantaranya adalah sebagai kota pendidikan. Yang menjadi indikator nya adalah meningkatnya siswa ataupun mahasiswa yang berasal dari luar kota Yogyakarta bahkan luar pulau Jawa menyekolahkan anak-anak mereka di Yogyakarta. Pantaslah predikat kota pelajar disematkan bagi Yogyakarta. 
Dari hasil pembahasan dalam penelitian ini, peneliti dapat menarik suatu kesimpulan sebagai berikut, Strategi promosi penerimaan siswa baru di SMK Kesehatan Ciptha Bhakti Husada dibuka di awali dengan tingginya animo masyarakat terkait tenaga kesehatan. Momentum inilah yang dipakai oleh pihak yayasan untuk mendirikan sekolah kejuruan dengan dua program keahlian. Terbukti pada tiga tahun pertama semenjak awal berdirinya jumlah yang mendaftar mengalami peningkatan yang cukup signifikan.

Salah satu faktor pendukung adalah momentum kebutuhan untuk tenaga kesehatan lagi banyak dibutuhkan sehingga peminat masuk di sekolah kejuruan menjadi ramai. Banyaknya yang mendaftar disesuaikan dengan daya tampung kelas yang dimiliki sekolah. Sehingga seleksi pun berjalan sesuai aturan.

Strategi promosi yang lain adalah dengan jalan melakukan kerjasama antara pihak sekolah dengan sekolah menengah pertama. Selain itu program promosi yang dilakukan adalah dalam bentuk presentasi, menempel poster dan mendistribusikan brosur kepada seluruh siswa kelas IX (Sembilan).

\section{DAFTAR PUSTAKA}

\section{BUKU}

Batra, Rajeev., John G. Myers., David A. Aaker. 1995. Advertising Management. Prentice Hall, $5^{\text {th }}$ ed.

Belch, George E., and Michael A. Belch. 2004. Advertising and Promotion: An Integrated Marketing Communications Perspective. Mc. Graw-Hill, $6{ }^{\text {th }}$ ed.

Bogdan, Robert., and Steven J. Taylor. 1975. Introduction To Qualitative Research Methods: A Phenomenological Approach To The Social Sciences. John Wiley and Sons.

Hidayat, Ara, \& Imam Machali, Pengelolaan Pendidikan (Konsep, Prinsip, dan Aplikasi dalam Mengelola Sekolah dan Madrasah). Yogyakarta: Kaukaba. 2012.

Kartajaya, Hermawan dan Yuswohady. 2005. Attracting Tourists, Traders, Investors: Strategi Memasarkan Daerah di Era Otonomi. Jakarta: MarkPlus\&Co.

Kasali, Rhenald. 2003. Membidik Pasar Indonesia: Segmentasi, Targeting dan Positioning. Jakarta: Gramedia Pustaka Utama. Cet. 6.

Kotler, Philip dan Gary Armstrong. 2001. Prinsip-Prinsip Pemasaran (alih bahasa, Damos Sihombing). Jakarta: Erlangga, Ed. 8.

Kotler, Philip., John Bowen, James Makens. 2002. Pemasaran Perhotelan dan Kepariwisataan (alih bahasa: Alexander Sindoro). Jakarta: Prehallindo, Jilid 1.

Miles, Matthew B. dan A. Michael Huberman. 1992. Analisis Data Kualitatif: Buku Sumber Tentang Metode-Metode Baru (Penerjemah: Tjetjep Rohendi Rohidi). Jakarta: Penerbit Universitas Indonesia (UI-Press). Cet. 1.

Moleong, Lexy J. 2005. Metodologi Penelitian Kualitatif. Bandung: PT Remaja Rosdakarya. Cet. 21.

Muhajir, Noeng. 1989. Metode Penelitian Kualitatif. Yogyakarta: Rake Sarasin. 
p-ISSN: 2338-9176

ChanNEL, Vol. 6, No. 1, April 2018, hal. 96-105

e-ISSN: 2621-2579

\section{INTERNET}

http://publikasi.data.kemdikbud.go.id/uploadDir/isi_234E39B6-621B-40AD-8E1EFB84611A804D_.pdf 